\author{
AUS DEM LEHRSTUHL \\ FÜR INNERE MEDIZIN II \\ DIREKTOR: PROF. DR. MED. G. A. J. RIEGGER \\ DER FAKULTÄT FÜR MEDIZIN \\ DER UNIVERSITÄT REGENSBURG
}

HIGH-SENSITIVE TROPONIN I IN ACUTE CARDIAC CONDITIONS: IMPLICATIONS OF BASELINE AND SEQUENTIAL MEASUREMENTS FOR DIAGNOSIS OF MYOCARDIAL INFARCTION

\author{
Inaugural - Dissertation \\ zur Erlangung des Doktorgrades \\ der Medizin \\ der \\ Fakultät für Medizin \\ der Universität Regensburg
}

vorgelegt von

Tobias Gassenmaier 



\author{
AUS DEM LEHRSTUHL \\ FÜR INNERE MEDIZIN II \\ DIREKTOR: PROF. DR. MED. G. A. J. RIEGGER \\ DER FAKULTÄT FÜR MEDIZIN \\ DER UNIVERSITÄT REGENSBURG
}

HIGH-SENSITIVE TROPONIN I IN ACUTE CARDIAC CONDITIONS: IMPLICATIONS OF BASELINE AND SEQUENTIAL MEASUREMENTS FOR DIAGNOSIS OF MYOCARDIAL INFARCTION

\author{
Inaugural - Dissertation \\ zur Erlangung des Doktorgrades \\ der Medizin \\ der \\ Fakultät für Medizin \\ der Universität Regensburg
}

vorgelegt von

Tobias Gassenmaier 
Dekan:

1. Berichterstatter:

2. Berichterstatter:

Tag der mündlichen Prüfung:
Prof. Dr. Dr. Torsten E. Reichert

Prof. Dr. Andreas Luchner

PD Dr. York Zausig

24. September 2012 
Inhaltsverzeichnis

Originalpublikation $\quad 1$

Zusätzliche online verfügbare Abbildungen und Tabellen 8

Deutsche Zusammenfassung 11

$\begin{array}{ll}\text { Danksagung } & 26\end{array}$

$\begin{array}{ll}\text { Lebenslauf } & 27\end{array}$ 


\title{
High-sensitive Troponin I in acute cardiac conditions: Implications of baseline and sequential measurements for diagnosis of myocardial infarction
}

\author{
Tobias Gassenmaier ${ }^{\mathrm{a}}$, Stefan Buchner ${ }^{\mathrm{a}}$, Christoph Birner ${ }^{\mathrm{a}}$, Carsten G. Jungbauer ${ }^{\mathrm{a}}$, Markus Resch ${ }^{\mathrm{a}}$, \\ Kurt Debl ${ }^{a}$, Dierk H. Endemann ${ }^{a}$, Guenter A.J. Riegger ${ }^{a}$, Petra Lehn ${ }^{b}$, Gerd Schmitz ${ }^{b}$, Andreas Luchner ${ }^{a}, *$ \\ a Klinik und Poliklinik fuer Innere Medizin II, Universitaetsklinikum Regensburg, 93053 Regensburg, Germany \\ ${ }^{\mathrm{b}}$ Institut fuer Klinische Chemie und Laboratoriumsmedizin, Universitaetsklinikum Regensburg, 93053 Regensburg, Germany
}

\section{A R T I C L E I N F O}

\section{Article history:}

Received 25 July 2011

Received in revised form 2 February 2012

Accepted 3 February 2012

Available online 14 February 2012

\section{Keywords:}

High-sensitive Troponin I

Myocardial infarction

Acute coronary syndrome

Non-ischemic cardiac disease

Cardiac markers

\begin{abstract}
A B S T R A C T
Background: High-sensitive Troponin I (hsTnI) facilitates the early diagnosis of myocardial infarction (MI). However, since hsTnI has not been well characterized in non-ischemic cardiac conditions, the predictive value of hsTnI for MI remains unclear.

Methods: hsTnI (ADVIA Centaur, Siemens) on admission was analyzed in 929 patients with acute cardiac condition and invasive ascertainment of coronary status by catheterization.

Results: Hs-TnI upon presentation was higher in patients with STEMI (median $1.27 \mathrm{ng} / \mathrm{mL}$, IQR $0.13-14.5 \mathrm{ng} / \mathrm{mL})$ as compared to patients with Non-STEMI $(0.66 \mathrm{ng} / \mathrm{mL}, \mathrm{IQR} 0.10-4.0 \mathrm{ng} / \mathrm{mL}, p<0.001)$ whereas it did not differ from STEMI in Tako-Tsubo cardiomyopathy $(2.57 \mathrm{ng} / \mathrm{mL}$, IQR $0.17-8.4 \mathrm{ng} / \mathrm{mL}$ ) and myocarditis $(9.76 \mathrm{ng} / \mathrm{mL}$, IQR $2.0-27.0 \mathrm{ng} / \mathrm{mL})$. In patients with resuscitation of non-ischemic cause $(0.31 \mathrm{ng} / \mathrm{mL}$, IQR $0.06-1.3 \mathrm{ng} / \mathrm{mL})$, acute heart failure $(0.088 \mathrm{ng} / \mathrm{mL}$, IQR $0.035-0.30 \mathrm{ng} / \mathrm{mL})$ and hypertensive emergency $(0.066 \mathrm{ng} / \mathrm{mL}$, IQR $0.032-0.34 \mathrm{ng} / \mathrm{mL})$, hs-TnI was elevated above the recommended threshold of $0.04 \mathrm{ng} / \mathrm{mL}$. At this cutpoint of $0.04 \mathrm{ng} / \mathrm{mL}$, hsTnI indicated acute MI (STEMI or Non-STEMI) with a sensitivity of $88 \%$ and a specificity of $45 \%$ (ROC-AUC 0.748 ). When patients with STEMI were excluded, hsTnI indicated Non-STEMI with a sensitivity of $87 \%$ and a specificity of $45 \%$ (ROC-AUC 0.725 ). When sequential measurements were taken into account in a restricted cohort, a maximum hsTnI of $\geq 0.40 \mathrm{ng} / \mathrm{mL}$ provided a sensitivity of $89 \%$ and a specificity of $85 \%$ (ROC-AUC 0.909 ) for Non-STEMI. Conclusions: HsTnI is a sensitive, albeit unspecific marker of MI. In patients with mildly elevated hsTnI and without evidence for STEMI, we suggest serial assessment of hsTnI and a 10-fold higher cutpoint of $0.40 \mathrm{ng} / \mathrm{mL}$ before Non-STEMI is assumed.
\end{abstract}

(c) 2012 Elsevier Ireland Ltd. All rights reserved.

\section{Introduction}

Cardiac troponin assays have revolutionized the diagnosis of acute myocardial infarction [1,2]. In fact, the elevation of troponin is often the only definite proof of myocardial infarction in the absence of ST-segment elevations. With the development of new high-sensitive troponin (hsTn) assays, detection limits have continuously been lowered over the last decade. Current high-sensitive assays allow assessing troponin with a coefficient of variation of $10 \%$ or less at the 99th percentile of a healthy reference population $[3,4]$. However, while hsTn has clearly facilitated the early

Abbreviations: hsTnI, high-sensitive Troponin I; MI, Myocardial infarction; STEMI, ST-elevation myocardial infarction; Non-STEMI, Non-ST-elevation myocardial infarction; ROC, Receiver operating characteristics; AUC, Area under the curve; ECG, Electrocardiography: MRI, Magnetic resonance imaging. TIMI, Thrombolysis in myocardial infarction; PCI, Percutaneous coronary intervention; PPV, Positive predictive value; NPV, Negative predictive value.

* Corresponding author. Tel.: +49 941944 7211; fax: +49 9419447213.

E-mail address: andreas.luchner@klinik.uni-regensburg.de (A. Luchner). diagnosis of myocardial ischemia, its serum concentrations in nonischemic cardiac conditions have not been well characterized. Moreover, patients reporting to the hospital with acute cardiac conditions differ markedly from the healthy reference population used for defining cut-off concentrations of troponin assays. In fact, the recent ESC guidelines on ACS state that there is an emerging need to distinguish chronic from acute troponin elevation in order to maintain specificity for MI and that relevant changes in levels from baseline are still debated [5]. Regarding treatment of patients with acute MI, current guidelines recommend urgent ascertainment of coronary status by cardiac catheterization. In order to assign patients with suspected MI to urgent cardiac catheterization with high confidence, the predictive values of the utilized cardiac markers should be as reliable as possible. However, the predictive value of hsTnI for myocardial infarction has not been determined in patients with acute cardiac conditions who are potential candidates for urgent catheterization.

It was therefore our aim to evaluate the frequency of ischemic and non-ischemic elevations of hsTnI and to assess the predictive values of hsTnI for MI. In order to address this aim, hsTnI was 
assessed in a large cohort of patients with acute cardiac condition and ascertainment of coronary status by cardiac catheterization.

\section{Methods}

\subsection{Patients}

All patients with acute cardiac conditions admitted to Regensburg University Hospital between October 2006 and November 2008 in whom hsTnI upon presentation and coronary status by cardiac catheterization were assessed, were retrospectively identified by chart review. Patients were categorized into 10 different groups according to their final discharge diagnosis. Of note, hsTnI levels on admission played no role in categorizing the patients. The STEMI group was defined as ST-elevation based on the ESC/ACCF/AHA/WHF guidelines as was the definition of Non-STEMI and unstable angina pectoris [6]. Patients who presented with initial symptoms of unstable angina pectoris were classified as either coronary artery disease or Non-STEMI, depending on the results of cardiac catheterization. If no occlusion, tight stenosis, or evidence of plaque rupture was found, patients were classified as coronary artery disease. Patients who showed no signs of high-grade coronary stenosis and no other signs of cardiac disease were classified as non-cardiac chest pain. Patients were classified as resuscitation of non-ischemic cause if their circulatory arrest was not due to stenotic coronary artery disease. This included patients with septicemia, intoxication, pancreatitis, respiratory failure caused by acute exacerbation of COPD, lactic acidosis and cerebral hemorrhage and bradycardia, hypokalaemia, cardiomyopathy, long QT syndrome and aneurysm of the ventricle. Tako-Tsubo cardiomyopathy was diagnosed if patients showed signs of apical ballooning and basal hypercontraction upon left ventricular cineangiography in the absence of high-grade coronary stenosis. Myocarditis was diagnosed if there was evidence of inflammatory myocardial disease due to typical ECG changes, inflammatory activation in serum, evidence for myocardial edema and late enhancement upon MRI and exclusion of high-grade coronary stenosis. Cardiac decompensation was defined as impaired left ventricular function with or without pulmonary congestion and exclusion of high-grade coronary stenosis. Hypertensive emergency was diagnosed if patients showed markedly elevated blood pressure prior to or at admission in the absence of high-grade coronary stenosis. Patients who did not meet the criteria for any of the groups above were classified as "others", including patients with anemia, pulmonary embolism, diabetic ketoacidosis, anaphylaxis, intoxication and hypotension because of exsiccosis. Classification of the patients was revised by an experienced interventional cardiologist and patients were excluded if their final diagnosis remained controversial.

\subsection{Biochemical analysis}

Measurements were taken from venous blood samples which were directly sent to the central laboratory and immediately analyzed as per standard protocol. No stored or frozen samples were used. According to the policy of our chest pain unit, a second sample for hsTnI was drawn after 3-4h when clinically indicated. HsTnI was measured by ADVIA Centaur ${ }^{\circledR}$ TnI-Ultra ${ }^{\mathrm{TM}}$ (Siemens Healthcare Diagnostics Inc.). Due to several isoforms immunological differentiation is realized by specific mono- and polyclonal antibodies binding to $\mathrm{N}$-terminal aminoacid sequences. High sensitivity is achieved by using chemiluminescent molecules producing light when they are excited by chemical energy. These emissions are measured by a light detector. The 99th percentile of the TnI-Ultra ${ }^{\mathrm{TM}}$ assay is at $0.04 \mathrm{ng} / \mathrm{mL}$. In our clinical practice and setting, this assay yields a coefficient of variation (VC) of $6.01 \%$ at $0.09 \mathrm{ng} / \mathrm{mL}, 4.50 \%$ at

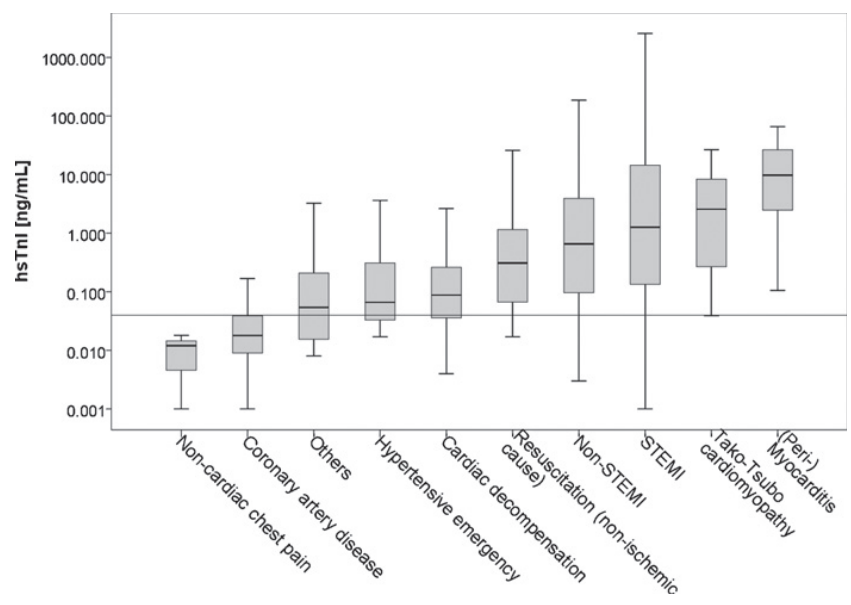

Fig. 1. hsTnI on admission. Horizontal line indicates concentration of $0.04 \mathrm{ng} / \mathrm{mL}$ Bars of the boxplot indicate median, interquartile range (25-75\%) and minimum and maximum observed (excluding outliers). Note logarithmic scale for hsTnI.

$1.6 \mathrm{ng} / \mathrm{mL}$ and $3.99 \%$ at $10.7 \mathrm{ng} / \mathrm{mL}$, indicating high sensitivity of the method. Thus, the assay meets recommended practice guidelines for clinical use in patients presenting with acute coronary syndromes. Analytical sensitivity of the assay amounts to $0.009 \mathrm{ng} / \mathrm{mL}$, defined as relative light units (RLU) scaling 2 standard deviations higher than the average RLUs of 20 repeated measurements of the TNI zero standard [7].

\subsection{Cardiac catheterization/coronary angiography}

Upon coronary angiography, coronary artery disease was classified as 1-vessel, 2-vessel or 3-vessel disease based on the number of coronary arteries showing a $>50 \%$ reduction of luminal diameter. Normal coronary arteries were defined as wall irregularities of $<10 \%$ lumen narrowing without left ventricular wall motion abnormalities and normal TIMI flow. Invasive diagnostics were performed in all patients using common techniques and $\mathrm{PCI}$ was performed if indicated.

\subsection{Statistical analysis}

All results for age and body mass index are expressed as means \pm standard deviation. All laboratory parameters are expressed as median and interquartile range. For between-group comparisons in normally distributed variables, we used the Student's $t$-test and otherwise the Mann-Whitney U-test. Normality of distribution was checked with the Kolmogorov-Smirnov test and the Shapiro-Wilk test before the T-test was applied. Categorical data were compared using Fisher's exact test. Due to the wide range of hsTnI levels, logarithmic scaling was chosen for graphical display in Fig. 1. In order to evaluate test performance of hsTnI as a predictor for myocardial infarction, the area under the curve (AUC) of the receiver operating characteristics (ROC) curve was calculated. A pvalue of $<0.05$ was considered statistically significant. Analysis was performed using PASW Statistics 17 (SPSS Inc.) and MedCalc.

\section{Results}

\subsection{Patient characteristics}

Patient characteristics are provided in Table 1 and results of laboratory measurements in Table 2 . The majority of patients (73\%) presented with myocardial infarction (STEMI 40\%, NonSTEMI 33\%). Myocarditis was the discharge diagnosis in $1.9 \%$ of 


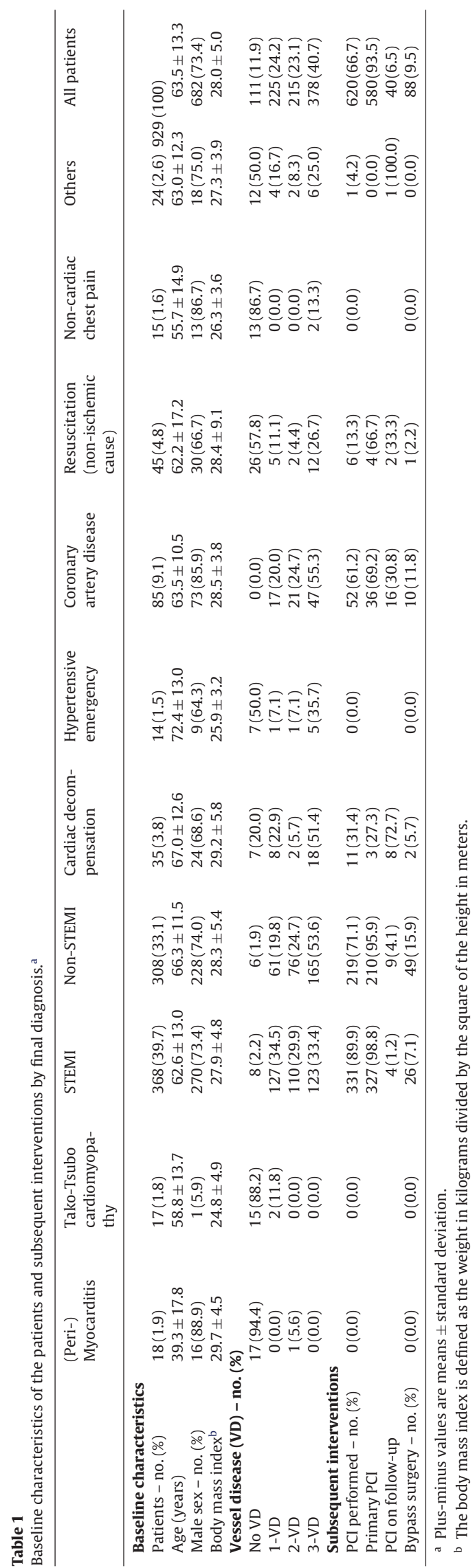

patients and Tako-Tsubo cardiomyopathy in $1.8 \%$ of patients. Coronary artery disease without acute ischemia was the final discharge diagnosis in $9.1 \%$ of patients, whereas $3.8 \%$ of patients suffered from cardiac decompensation and $1.5 \%$ from hypertensive emergency. $4.8 \%$ of patients underwent cardiac catheterization after resuscitation which eventually turned out to have a non-ischemic cause. Non-cardiac chest pain was the final diagnosis in $1.6 \%$ of patients. Overall, the majority of patients in all groups was of male gender (on average 73\%), except for Tako-Tsubo cardiomyopathy (each $p \leq 0.001$ ), with only one male patient out of 17. Patients with myocarditis were significantly younger (each $p \leq 0.005)$ and showed higher concentrations of C-reactive protein (each $p \leq 0.001$ ) than patients in the other groups. Among patients after resuscitation of non-ischemic cause, significantly higher concentrations of lactate dehydrogenase (each $p \leq 0.006$ ) and myoglobin (each $p \leq 0.026$ ) were observed (Table 2 ).

\subsection{Spectrum of admission hsTnI across acute cardiac conditions}

The highest admission levels of hsTnI (Fig. 1) were observed in patients with myocarditis (median $9.76 \mathrm{ng} / \mathrm{mL}$ ), Tako-Tsubo cardiomyopathy (median $2.57 \mathrm{ng} / \mathrm{mL}$ ) and STEMI (median $1.27 \mathrm{ng} / \mathrm{mL}$, all $p=$ n.s.). As compared to STEMI, hsTnI was lower in Non-STEMI (median $0.66 \mathrm{ng} / \mathrm{mL}, p<0.001$ ), resuscitation of non-ischemic cause (median $0.31 \mathrm{ng} / \mathrm{mL}, \quad p=0.001$ ), cardiac decompensation (median $0.088 \mathrm{ng} / \mathrm{mL}, p<0.001$ ) and hypertensive emergency (median $0.066 \mathrm{ng} / \mathrm{mL}, p=0.001$ ). With a median of $0.012 \mathrm{ng} / \mathrm{mL}$ and $0.018 \mathrm{ng} / \mathrm{mL}$, respectively, most patients with the final diagnosis of non-cardiac chest pain and coronary artery disease had levels below the recommended cut-off concentration of $0.04 \mathrm{ng} / \mathrm{mL}$.

\subsection{Maximum hsTnI across cardiac conditions}

The general distribution of maximum hsTnI during follow-up was similar to the distribution of hsTnI on admission (Fig. 4, supplemental material), albeit the highest maximum concentrations were observed in patients with STEMI (median $32.47 \mathrm{ng} / \mathrm{mL}$ ) instead of patients with myocarditis (median $27.57 \mathrm{ng} / \mathrm{mL}, p=\mathrm{n} . \mathrm{s}$.). Patients with STEMI had significantly higher maximum hsTnI levels than patients with Tako-Tsubo cardiomyopathy (median $5.42 \mathrm{ng} / \mathrm{mL}, p=0.002$ ), Non-STEMI (median $3.36 \mathrm{ng} / \mathrm{mL}$ ), resuscitation of non-ischemic cause (median $1.88 \mathrm{ng} / \mathrm{mL}$ ), hypertensive emergency (median $0.38 \mathrm{ng} / \mathrm{mL}$ ), cardiac decompensation (median $0.21 \mathrm{ng} / \mathrm{mL}$ ), coronary artery disease (median $0.030 \mathrm{ng} / \mathrm{mL}$ ) and non-cardiac chest pain (median $0.022 \mathrm{ng} / \mathrm{mL}$; each $p<0.001$ ). As compared to hsTnI levels on admission, the strongest rise in maximum hsTnI levels was therefore observed in patients with STEMI $(26 \times)$, followed by patients with resuscitation of nonischemic cause, hypertensive emergency (both $6 \times$ ), Non-STEMI $(5 \times)$, myocarditis $(3 \times)$, cardiac decompensation and Tako-Tsubocardiomyopathy (both $2 \times$ ) (Fig. 5, supplemental material).

\subsection{Predictive values of admission and follow-up hsTnI for myocardial infarction (Table 3)}

The predictive values of hsTnI upon admission and follow-up for acute myocardial infarction (Non-STEMI and STEMI) as determined by ROC analysis (AUC $0.748, p<0.001$ ) are depicted in Fig. 2. Regarding admission hsTnI, sensitivity was $88 \%$ and specificity $45 \%$ for the clinical recommended cut-off concentration of $0.04 \mathrm{ng} / \mathrm{mL}$. For an optimized cutpoint of $0.10 \mathrm{ng} / \mathrm{mL}$, sensitivity was $77 \%$ and specificity was $63 \%$, respectively. For the diagnosis of Non-STEMI alone, sensitivity was $87 \%$ and specificity was $45 \%$ at the recommended cut-off concentration of $0.04 \mathrm{ng} / \mathrm{mL}$ (AUC $0.725, p<0.001$ ) and $74 \%$ and $63 \%$, respectively, at the optimized cut-off concentration of $0.10 \mathrm{ng} / \mathrm{mL}$. 


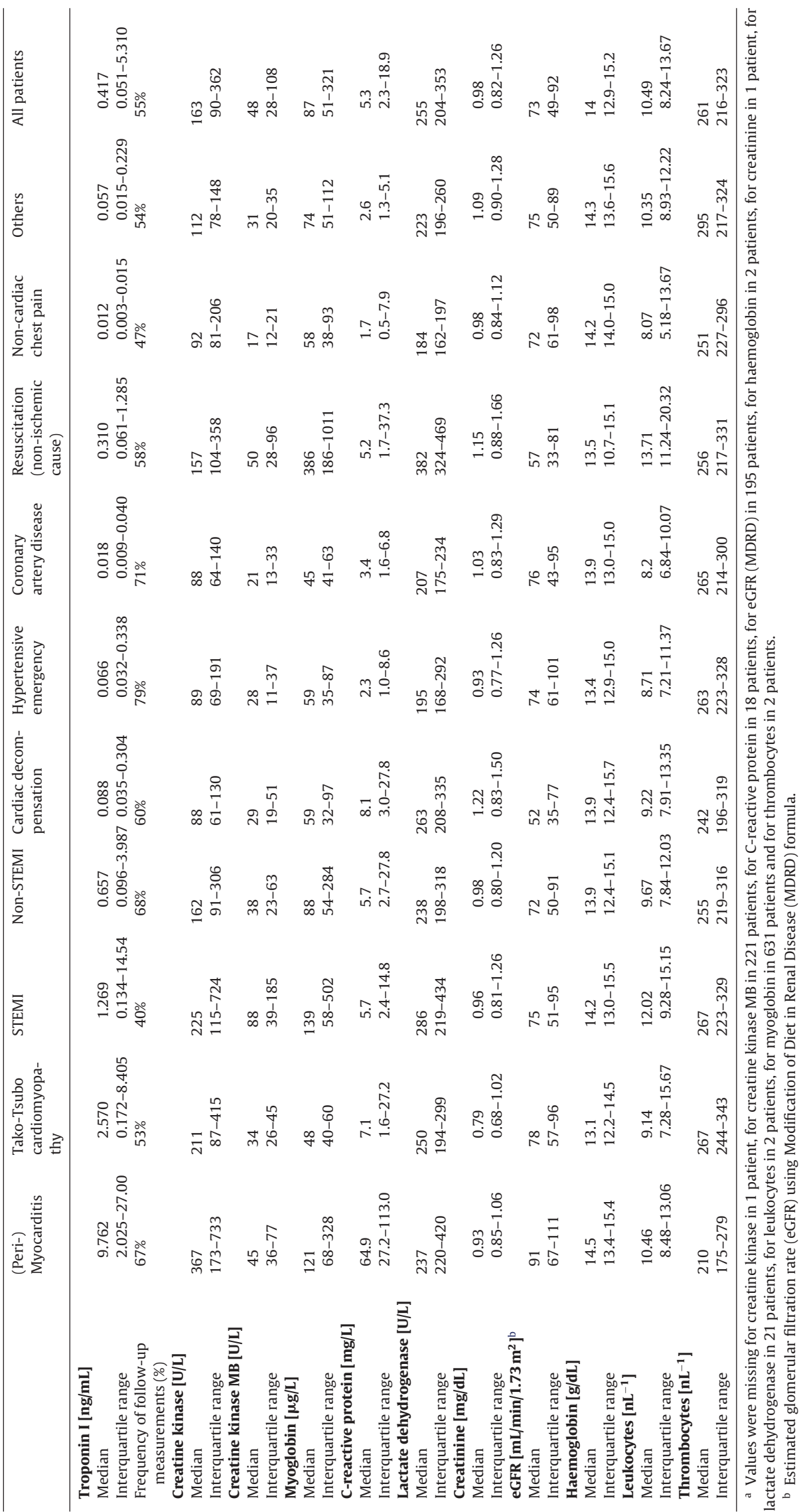


Table 3

Predictive values of hsTnI to indicate NSTEMI (STEMI excluded from analysis).

\begin{tabular}{|c|c|c|c|c|c|c|c|c|}
\hline & $N$ & $n$ (NSTEMI) & Prevalence & Sensitivity & Specificity & PPV & NPV & Accuracy \\
\hline \multicolumn{9}{|c|}{ hsTnI (baseline) } \\
\hline$>0.04 \mathrm{ng} / \mathrm{mL}$ & 561 & 308 & $55 \%$ & $87 \%$ & $45 \%$ & $66 \%$ & $75 \%$ & $68 \%$ \\
\hline \multicolumn{2}{|c|}{ hsTnI (follow-up) } & 308 & $55 \%$ & $74 \%$ & $63 \%$ & $71 \%$ & $67 \%$ & $69 \%$ \\
\hline$>0.04 \mathrm{ng} / \mathrm{mL}$ & 367 & 208 & $57 \%$ & $99 \%$ & $35 \%$ & $62 \%$ & $96 \%$ & $67 \%$ \\
\hline \multirow[t]{2}{*}{$>0.40 \mathrm{ng} / \mathrm{mL}$} & 367 & 208 & $57 \%$ & $89 \%$ & $62 \%$ & $76 \%$ & $81 \%$ & $77 \%$ \\
\hline & $320^{a}$ & 208 & $65 \%$ & $89 \%$ & $85 \%$ & $91 \%$ & $80 \%$ & $87 \%$ \\
\hline
\end{tabular}

a Restricted cohort.

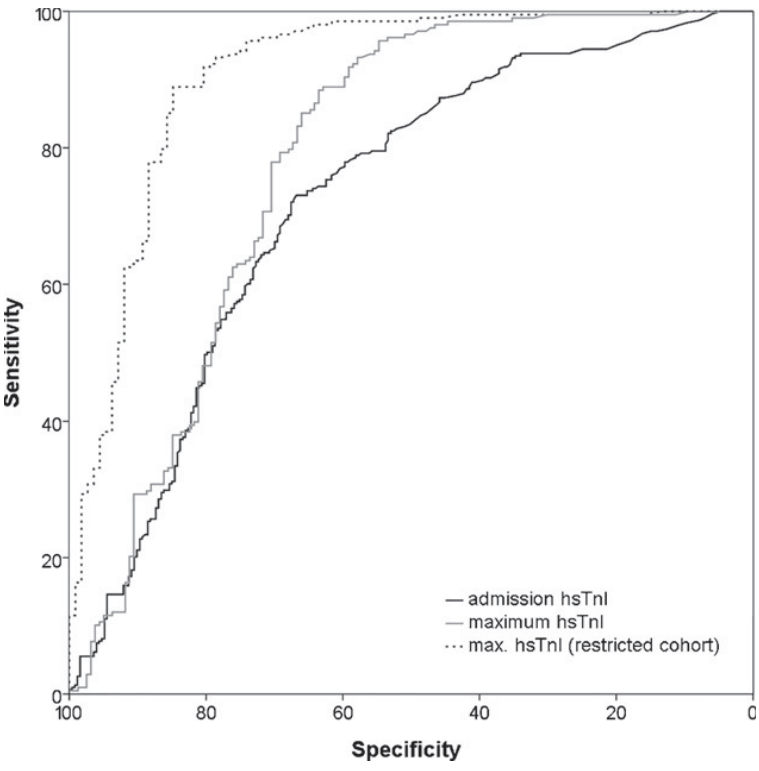

Fig. 2. ROC-curves for correct diagnosis of non-STEMI by hsTnI. Patients with STEMI excluded. In the restricted cohort, patients with Tako-Tsubo cardiomyopathy, myocarditis and resuscitation of non-ischemic cause were excluded.

In addition to hsTnI on admission, we also assessed the predictive values of maximum follow-up hsTnI. We found that a cutoff at $0.04 \mathrm{ng} / \mathrm{mL}$ hsTnI on follow-up achieved predictive values of $99 \%$ sensitivity and $35 \%$ specificity for the diagnosis of myocardial infarction, which did not change after exclusion of patients with STEMI. However, when a 10 -fold higher cutpoint of $0.40 \mathrm{ng} / \mathrm{mL}$ was considered and patients with STEMI, Tako-Tsubo cardiomyopathy, myocarditis and resuscitation of non-ischemic cause were excluded (restricted cohort, Fig. 2), higher predictive values were achieved with a sensitivity of $89 \%$ and a specificity of $85 \%$ for the diagnosis of Non-STEMI.

\subsection{Implications of hsTnI for urgent cardiac catheterization}

In the current population only $81 \%$ of patients with admission hsTnI of $\geq 0.04 \mathrm{ng} / \mathrm{mL}$ had the final diagnosis of STEMI or Non-STEMI. Therefore, $19 \%$ of all cardiac catheterizations were performed in patients without acute myocardial infarction. As also patients with admission hsTnI levels below $0.04 \mathrm{ng} / \mathrm{mL}$ underwent early-invasive or urgent cardiac catheterization, the percentage of patients with coronary angiography but without a final diagnosis of myocardial infarction was $27 \%$. Assuming that only patients with admission hsTnI levels higher than the optimized cut-off concentration of $0.10 \mathrm{ng} / \mathrm{mL}$ would have undergone catheterization, the rate of patients without myocardial infarction would have been lowered from $27 \%$ to $15 \%$.

\section{Discussion}

The present study evaluated hsTnI as marker for acute myocardial infarction in a cohort of patients across the spectrum of acute cardiac conditions who all underwent invasive ascertainment of coronary status. Our data demonstrate that hsTnI is a very sensitive tool for detecting myocardial injury, albeit unspecific for myocardial infarction. Other potential and clinically important diseases that may lead to release of hsTnI are cardiac decompensation, hypertensive emergency, myocarditis, Tako-Tsubo cardiomyopathy and resuscitation of non-ischemic cause. Admission hsTnI only achieves reasonable predictive values if the latter three diagnoses are excluded. As a consequence, optimal cutpoints for the diagnosis of myocardial infarction are above the reference cutpoint of the 99th percentile of normal. We observed further, that the predictive values of hsTnI improve with repeated testing and that Non-STEMI can be assumed if hsTnI exceeds $0.40 \mathrm{ng} / \mathrm{mL}$ during repeated testing. If the decision for urgent or early-invasive cardiac catheterization relies on hsTnI, up to $30 \%$ negative coronary findings can be expected.

\subsection{HsTnI for the detection of acute myocardial infarction}

High-sensitive Troponin I assays have been reported to achieve sensitivities and specificities as high as $84 \%$ to $94 \%$ for the detection of acute myocardial infarction using the cut-off concentration at the 99th percentile of normal $[3,4]$. The current study showed comparable results for sensitivity with $88 \%$. However, specificity for detecting acute myocardial infarction was only $45 \%$ in our cohort at the cut-off concentration of $0.04 \mathrm{ng} / \mathrm{mL}$. This discrepancy is likely due to the different study designs and definitions of myocardial infarction between these studies. In the study by Reichlin et al. [4], patients were included if they presented with signs of acute myocardial infarction, the onset or peak of which had occurred not longer than $12 \mathrm{~h}$ ago. Myocardial infarction was defined as clinical signs of myocardial ischemia in association with at least one troponin value above the 99th percentile. In the study by Keller et al. [3], patients were included if they presented with new-onset chest pain and myocardial infarction was defined as a rise or fall in the hsTnI value of $30 \%$ or more within $6 \mathrm{~h}$ after admission combined with at least one value of more than $0.04 \mathrm{ng} / \mathrm{mL}$. As compared to our current study, specificity of the troponin assays may have been overestimated by these previous studies since the diagnosis of myocardial infarction was often not verified by coronary angiography and all other acute cardiac conditions may as well present with unspecific ECG-changes and dynamic changes of hsTnI. Interestingly, a recent prospective study by Javed et al. also showed that in a cohort of 701 patients with elevated troponin levels, only $31 \%$ actually had myocardial infarction [8].

In contrast to the above-mentioned studies, the novelty of the current study is the fact that is uses invasive ascertainment of coronary status in all patients. It shows that Tako-Tsubo cardiomyopathy and myocarditis as well as cardiac decompensation, hypertensive emergency and resuscitation of non-ischemic 


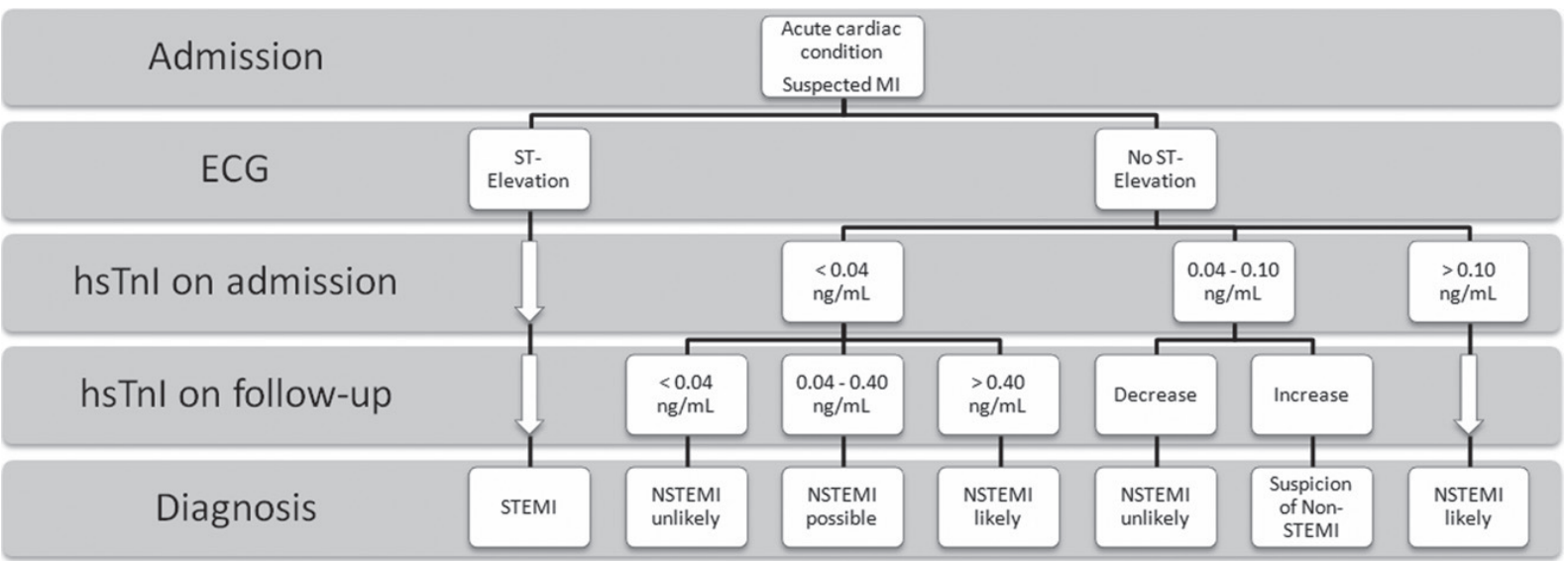

Fig. 3. Suggested clinical pathway for patients with acute cardiac condition and suspected myocardial infarction. For predictive values refer to Table 3 .

cause can lead to significantly elevated hsTnI and allows ranking these respective elevations with respect to their magnitude. Together, our and other data clearly indicate that it is impossible to sufficiently discriminate between myocardial infarction and non-ischemic myocardial damage solely on the basis of hsTnI levels $[9,10]$.

\subsection{Improving the predictive value of $h s T n I$ for myocardial infarction}

To improve the predictive values of hsTnI for myocardial infarction, we assessed two possible strategies, namely higher cutpoints and serial testing. Rising the cutpoint of hsTnI on admission or on follow-up does in fact markedly reduce the number of "positive" test results in patients with diagnoses other than myocardial infarction. However, it also reduces the number of positive test results in patients with Non-STEMI, an effect that is more apparent with hsTnI on admission than on follow-up. After exclusion of patients with STEMI, which do not require positive biomarkers to establish the diagnosis, the predictive values for myocardial infarction (i.e. Non-STEMI) achieved a sensitivity of $87 \%$ and specificity of $45 \%$. Only after exclusion of Tako-Tsubo cardiomyopathy, myocarditis and resuscitation of non-ischemic cause did the predictive value of admission-hsTnI achieve a reasonable level. Of note, the optimal cutpoint exceeded the 99th percentile of normal and was $0.10 \mathrm{ng} / \mathrm{mL}$

Regarding serial testing, excellent predictive values were achieved with a sensitivity of $89 \%$ and a specificity of $85 \%$ for the diagnosis of Non-STEMI at a 10 -fold higher cutpoint of $0.40 \mathrm{ng} / \mathrm{mL}$ for maximum hsTnI, when patients with STEMI, Tako-Tsubo cardiomyopathy, myocarditis and resuscitation of non-ischemic cause were excluded (restricted cohort, ROC-AUC 0.909, Fig. 2). Interestingly, troponin levels increased in all acute cardiac conditions to some extent (2-26-fold). Although the exclusion of these latter conditions introduces some selection bias, it appears warranted, since they are relatively rare on the one hand. On the other hand, they are often highly dramatic and an urgent coronary angiogram in these patients is often warranted to conclusively exclude myocardial infarction. In contrast, the much more frequent conditions of decompensated heart failure, hypertensive emergency and tachyarrhythmia, which may as well present with elevated hsTnI but do not require urgent catheterization need to be differentiated from myocardial infarction with the highest possible degree of fidelity. In this respect, the proposed strategy of repeated testing and assuming myocardial infarction only if maximum hsTnl rises above $0.40 \mathrm{ng} / \mathrm{mL}$ provided the best discrimination. Indeed, whereas hsTnI exceeded $0.40 \mathrm{ng} / \mathrm{mL}$ in $88.9 \%$ of patients with NonSTEMI, it exceeded this threshold in only $29.7 \%$ of patients without myocardial infarction in the restricted cohort. This absolute difference of almost $60 \%$ was not reached by any other strategy (i.e. any threshold of hsTnI at presentation or maximum, for a complete overview see Table 4, supplemental material).

For practical purposes, we therefore recommend a strategy as presented in Fig. 3. This strategy is hypothesis-generating and needs to be tested prospectively. Possibly, such a strategy might also reduce redundant hsTn tests and save costs. Furthermore, current guidelines on the diagnosis of myocardial infarction need to be re-evaluated to better take non-ischemic elevations of hsTnI and the resulting implications for the correct diagnosis of myocardial infarction into account.

As an alternative to repeated measurement of $\mathrm{Tn}$, comeasurement of copeptin has been proposed in patients with negative first $\mathrm{Tn}$ in order to reduce the necessary time-interval for the exclusion of NSTEMI [11]. Future studies will help to clarify the relative benefits of sequential measurements of hsTn and co-measurement of copeptin together with hsTn.

Another possibility is the co-measurement of NT-proBNP, which was shown to indicate ischemic burden, reperfusion success and prognosis in patients with acute coronary syndrome [12].

\subsection{Implications of elevated hsTnI for urgent cardiac catheterization}

Reliably identifying patients with myocardial infarction in the emergency department is often a challenge for the treating physician [13]. Due to the urgency of the disease, it has become routine practice in many institutions that patients with elevated troponin levels undergo urgent or early-invasive cardiac catheterization, even if this results in a relevant number of "false positive" indications. In addition, even slightly elevated levels of hsTnI may be associated with increased long-term mortality and can point to cardiac diseases that require further attention and treatment [14-18]. Since the benefits of an early invasive strategy prevail in patients with myocardial infarction, a substantial percentage of negative coronary findings in urgent and early-invasive catheterizations in patients with elevated hsTnI (most often suspected Non-STEMI) is inevitable due to the low specificity of hsTnI [19]. Of note, a certain rate of false-negative coronary studies does not indicate inaccurate or negligent indication towards cardiac catheterization. Rather, it indicates an appropriate alertness for possible myocardial 
infarction. Nevertheless, on the basis of our and other results, it may be adequate to defer catheterization in stable patients without chest pain and only mildly elevated hsTnI (e.g. $0.04-0.40 \mathrm{ng} / \mathrm{mL}$ ) which does not increase further during repeat assessment [20].

\subsection{Limitations}

As only patients with coronary angiography and measurement of hsTnI on admission were included in the study, there may be some selection bias regarding the spectrum of acute cardiac conditions. However, invasive ascertainment of coronary status is inevitable as it is the only way to ensure the correct diagnosis. Other potential limitations are the facts that the data used are retrospective and single-center and that sequential measurements of hsTnI were not stipulated but performed by clinical consideration.

\section{Conclusion}

The current study evaluated hsTnI across the spectrum of acute cardiac conditions in a cohort of patients with invasive ascertainment of coronary status by cardiac catheterization. It shows that hsTnI is a sensitive, but not specific marker of myocardial ischemia as a number of non-ischemic diseases may also lead to relevant elevations of hsTnI. Rising the cutpoint of hsTnI from above the 99th percentile of a healthy reference population, e.g. from 0.04 to $0.10 \mathrm{ng} / \mathrm{mL}$, improves the specificity for myocardial infarction at a still acceptable sensitivity. It further shows that routine catheterization in patients with elevated hsTnI is necessarily associated with a relevant number of negative coronary findings and a potential overuse of urgent or early-invasive studies. In order to better differentiate Non-STEMI from non-ischemic elevations of hsTnI, a cutpoint of $0.40 \mathrm{ng} / \mathrm{mL}$ upon serial testing provided acceptable predictive values of hsTnI for myocardial infarction.

\section{Conflict of interest statement}

No financial or other relations that could lead to a conflict of interest.

\section{Appendix A. Supplementary data}

Supplementary data associated with this article can be found, in the online version, at doi:10.1016/j.atherosclerosis.2012.02.007.

\section{References}

[1] Hamm CW, Goldmann BU, Heeschen C, Kreymann G, Berger J, Meinertz T. Emergency room triage of patients with acute chest pain by means of rapid testing for cardiac troponin T or troponin I. N Engl J Med 1997;23:1648-53.

[2] Morrow DA, Cannon CP, Jesse RL, et al. National Academy of Clinical Biochemistry Laboratory Medicine Practice Guidelines: clinical characteristics and utilization of biochemical markers in acute coronary syndromes. Clin Chem 2007; 4:552-74

[3] Keller T, Zeller T, Peetz D, et al. Sensitive troponin I assay in early diagnosis of acute myocardial infarction. N Engl J Med 2009;9:868-77.

[4] Reichlin T, Hochholzer W, Bassetti S, et al. Early diagnosis of myocardial infarction with sensitive cardiac troponin assays. N Engl J Med 2009:9:858-67.

[5] Hamm CW, Bassand J, Agewall S, Bax J, Boersma E, Bueno H, et al. ESC Guidelines for the management of acute coronary syndromes in patients presenting without persistent ST-segment elevation: The Task Force for the management of acute coronary syndromes (ACS) in patients presenting without persistent ST-segment elevation of the European Society of Cardiology (ESC). Eur Heart J 2011;23:2999-3054.

[6] Thygesen K, Alpert JS, White HD. Universal definition of myocardial infarction. J Am Coll Cardiol 2007;22:2173-95.

[7] Casals G, Filella X, Bedini JL. Evaluation of a new ultrasensitive assay for cardiac troponin I. Clin Biochem 2007; 18:1406-13.

[8] Javed U, Aftab W, Ambrose JA, et al. Frequency of elevated troponin I and diagnosis of acute myocardial infarction. Am J Cardiol 2009;1:9-13.

[9] Tsutamoto T, Kawahara C, Nishiyama K, et al. Prognostic role of highly sensitive cardiac troponin I in patients with systolic heart failure. Am Heart J 2010;1:63-7.

[10] Vidi V, Rajesh V, Singh PP, et al. Clinical characteristics of tako-tsubo cardiomyopathy. Am J Cardiol 2009;4:578-82.

[11] Keller T, Tzikas S, Zeller T, et al. Copeptin improves early diagnosis of acute myocardial infarction. J Am Coll Cardiol 2010;19:2096-106.

[12] Buchner S, Debl K, Barlage S, et al. Dynamic changes in N-terminal pro-brain natriuretic peptide in acute coronary syndromes treated with percutaneous coronary intervention: a marker of ischemic burden, reperfusion and outcome. Clin Chem Lab Med 2010;6:875-81.

[13] Bassand J, Hamm CW, Ardissino D, et al. Guidelines for the diagnosis and treatment of non-ST-segment elevation acute coronary syndromes. Eur Heart J 2007;13:1598-660.

[14] Eggers KM, Lagerqvist B, Venge P, Wallentin L, Lindahl B. Persistent cardiac troponin I elevation in stabilized patients after an episode of acute coronary syndrome predicts long-term mortality. Circulation 2007;17:1907-14.

[15] Horwich TB, Patel J, MacLellan WR, Fonarow GC. Cardiac troponin I is associated with impaired hemodynamics, progressive left ventricular dysfunction, and increased mortality rates in advanced heart failure. Circulation 2003;7:833-8.

[16] Korff S, Katus HA, Giannitsis E. Differential diagnosis of elevated troponins. Heart 2006;7:987-93.

[17] You JJ, Austin PC, Alter DA, Ko DT, Tu JV. Relation between cardiac troponin I and mortality in acute decompensated heart failure. Am Heart J 2007;4:462-70.

[18] Zethelius B, Johnston N, Venge P. Troponin I as a predictor of coronary heart disease and mortality in 70-year-old men: a community-based cohort study. Circulation 2006;8:1071-8.

[19] Hoenig MR, Aroney CN, Scott IA. Early invasive versus conservative strategies for unstable angina and non-ST elevation myocardial infarction in the stent era. Cochrane Database Syst Rev 2010;3:CD004815.

[20] Navarese EP, de Servi S, Gibson CM, et al. Early vs. delayed invasive strategy in patients with acute coronary syndromes without ST-segment elevation: a meta-analysis of randomized studies. OJM 2011;3:193-200. 


\section{Zusätzliche online verfügbare Abbildungen und Tabellen}

Figure 4: Admission and maximum hsTnl - Horizontal line indicates concentration of $0.04 \mathrm{ng}$ per $\mathrm{mL}$

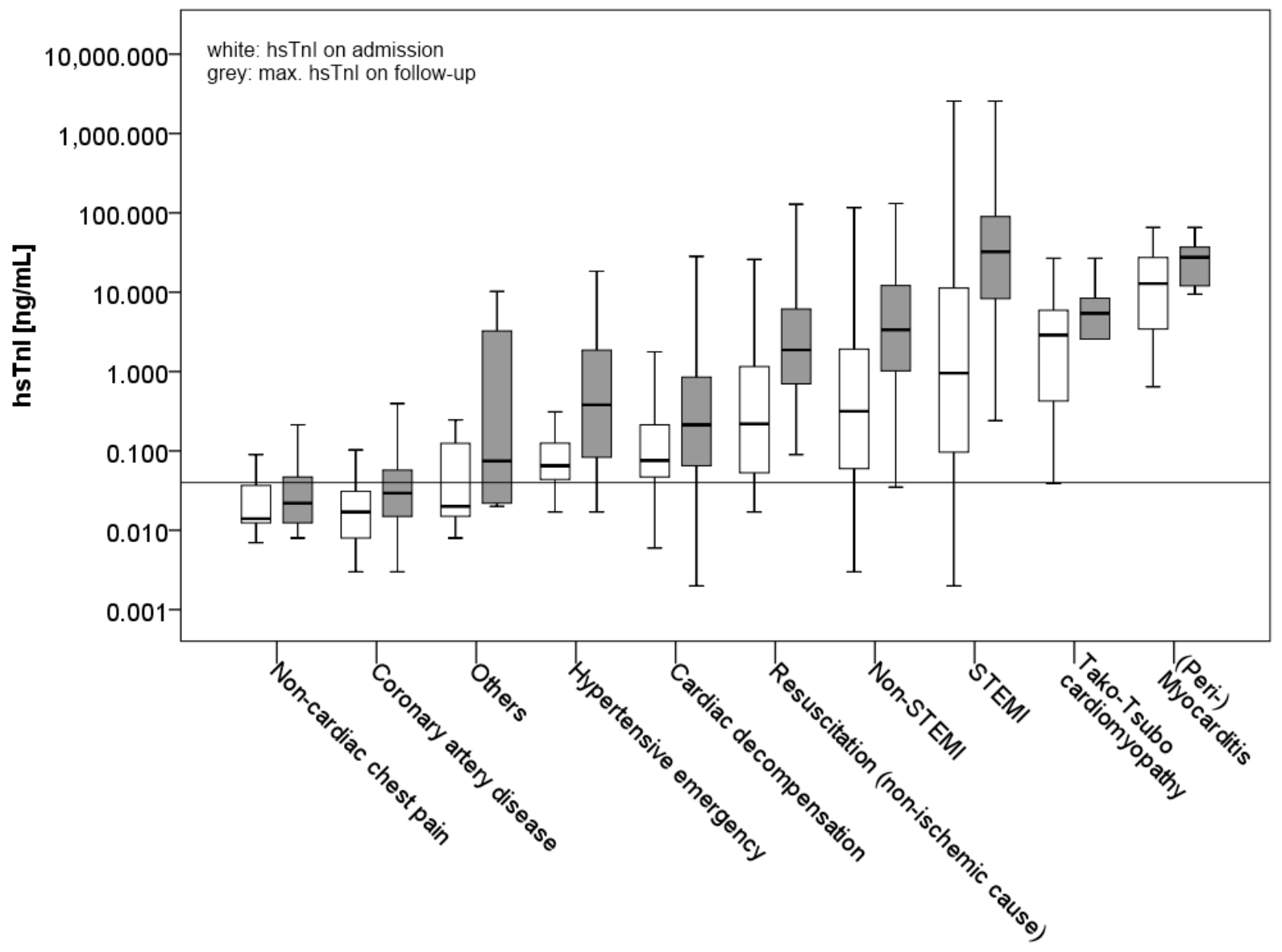


Figure 5: X-fold relative increase of maximum hsTnl in comparison to admission

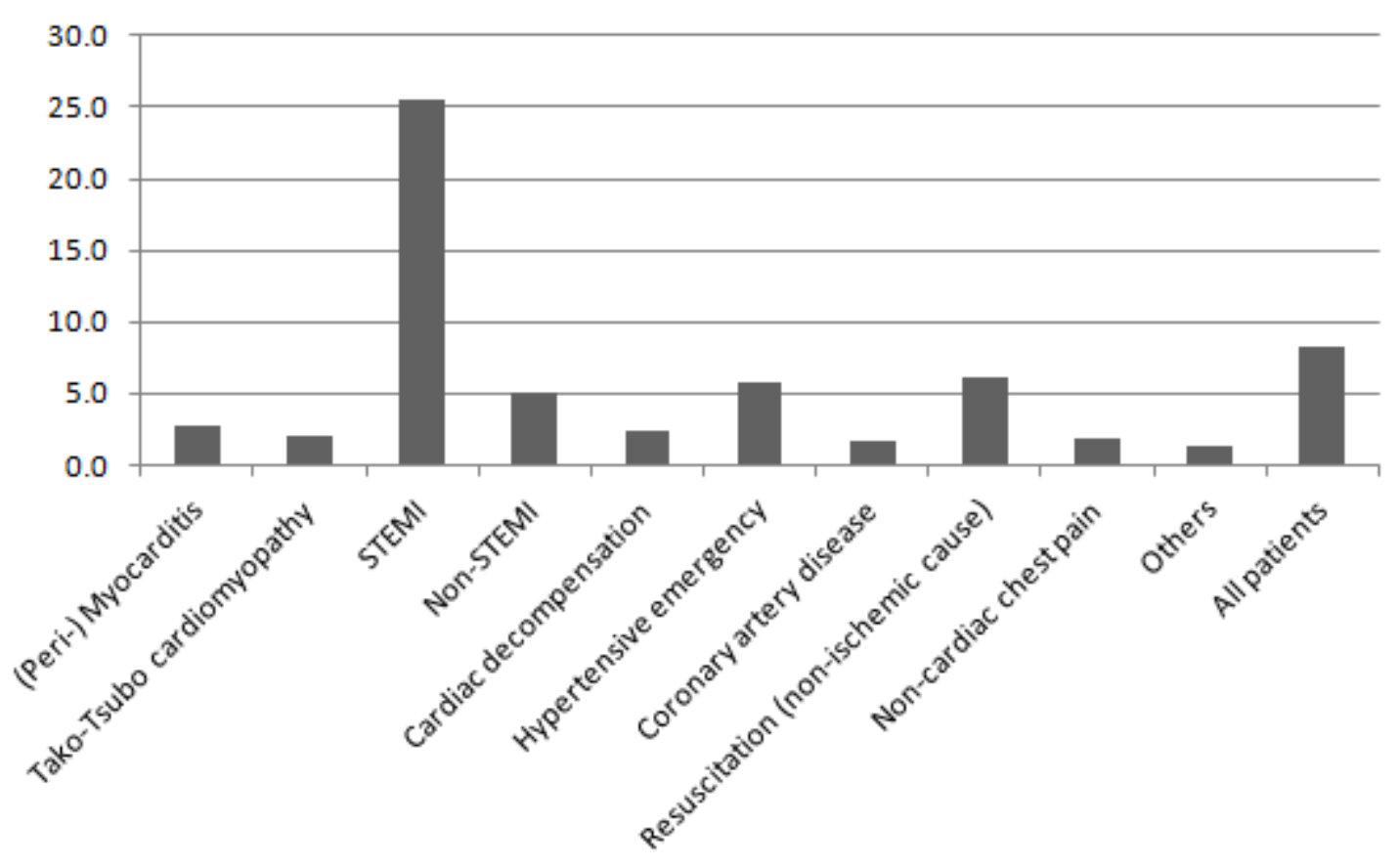


Table 4: Proportion of patients with hsTnl above specified cutpoint (in percent)

STEMI ( $n=368) \quad$ Myocarditis ( $n=18)$ Tako-Tsubo $(n=17) \quad$ NSTEMI $(n=308) \quad$ Other $(n=218)$

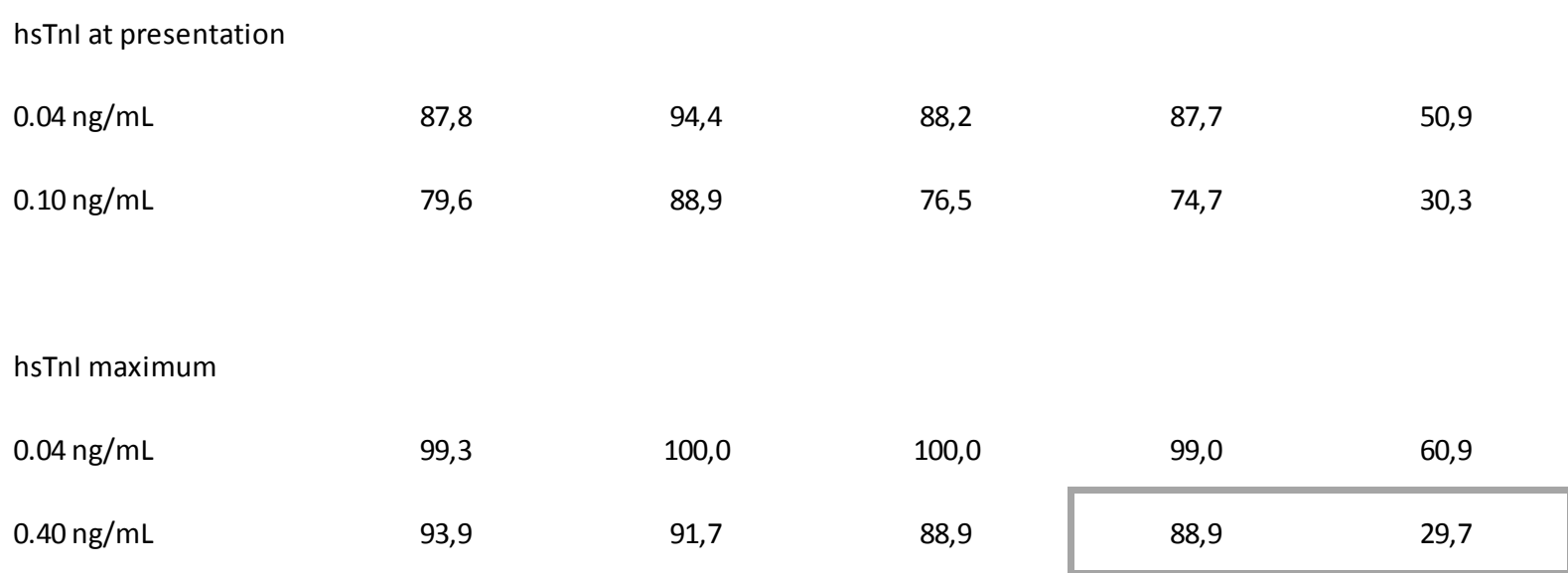




\section{High-sensitive Troponin I in acute cardiac conditions: Implications of baseline and sequential measurements for diagnosis of myocardial infarction}

Tobias Gassenmaier ${ }^{a}$, Stefan Buchner ${ }^{a}$, Christoph Birner ${ }^{a}$, Carsten G. Jungbauer ${ }^{a}$, Markus Resch $^{a}$, Kurt Debl ${ }^{a}$, Dierk H. Endemann ${ }^{a}$, Günter A. J. Riegger ${ }^{a}$, Petra Lehn ${ }^{b}$, Gerd Schmitz $^{b}$, Andreas Luchner ${ }^{a}$

a Klinik und Poliklinik für Innere Medizin II, Universitätsklinikum Regensburg, 93053 Regensburg, Germany

${ }^{b}$ Institut für Klinische Chemie und Laboratoriumsmedizin, Universitätsklinikum Regensburg, 93053 Regensburg, Germany

publiziert in Atherosclerosis, Volume 222, Issue 1, Pages 116-122, May 2012

Deutsche Zusammenfassung 


\section{Hochsensitives Troponin I bei akuten kardialen Erkrankungen: Aussagekraft von Aufnahme- und Verlaufswerten für die Diagnose des akuten Myokardinfarktes}

\section{Einleitung}

Tests zur Bestimmung der Konzentration der kardialen Troponine haben die Diagnostik des Myokardinfarktes revolutioniert. Insbesondere im Falle der Abwesenheit von ST-Strecken-Hebungen im EKG sind sie oft der einzige eindeutige Hinweis auf einen akuten Myokardinfarkt. Mit der Entwicklung neuer, hochsensitiver Troponintests wurden die Nachweisgrenzen während des letzten Jahrzehntes kontinuierlich gesenkt. Aktuelle hochsensitive Tests erlauben die Troponinbestimmung mit einem Variationskoeffizienten von weniger als $10 \%$ an der 99 . Perzentile einer gesunden Referenzpopulation. Trotz dieser Vorzüge der hochsensitiven Troponintests wurden die Serumkonzentrationen dieses Markers bei nicht-ischämischen kardialen Erkrankungen bisher nicht umfassend untersucht. Darüber hinaus unterscheiden sich die Patienten in der Notaufnahme einer Klinik in aller Regel deutlich von der gesunden Referenzpopulation, welche zur Bestimmung der Grenzwerte dieser Tests herangezogen wird. Auch die Europäische Gesellschaft für Kardiologie betont ihn ihren aktuellen Leitlinien zum akuten Koronarsyndrom, dass die Unterscheidung zwischen akuten und chronischen Troponinerhöhungen von zunehmender Relevanz ist und dass noch nicht abschließend geklärt ist, ab welchem Wert von einem signifikanten Anstieg ausgegangen werden muss. Hinsichtlich der Therapie von Infarktpatienten empfehlen die aktuellen Leitlinien die zügige Durchführung einer Koronarangiographie. Um effektiv diejenigen Patienten zu selektionieren, die von diesem Eingriff profitieren, sollten die verwendeten Labormarker daher einen möglichst hohen prädiktiven Wert für die Diagnose des akuten Myokardinfarktes haben. Dieser Vorhersagewert ist jedoch bislang für das hochsensitive Troponin I (hsTnl) bei Patienten mit Verdacht auf akutes 
Koronarsyndrom und möglicher Indikation für eine Koronarangiographie noch nicht hinreichend bestimmt worden.

Es war daher das Ziel der vorliegenden Arbeit, das Ausmaß und den Verlauf von ischämischen und nicht-ischämischen hsTnl-Erhöhungen zu untersuchen und die prädiktiven Werte für die Diagnose eines akuten Myokardinfarktes zu bestimmen. Um dieses Ziel zu erreichen, wurde hsTnl in einer großen Kohorte von Patienten mit Verdacht auf akutes Koronarsyndrom und nachfolgender Koronarangiographie bestimmt. 


\section{Methoden}

\section{Patienten}

Alle Patienten, die mit Verdacht auf akutes Koronarsyndrom zwischen Oktober 2006 und November 2008 in das Universitätsklinikum Regensburg eingeliefert wurden und bei denen sowohl hsTnl bei Aufnahme bestimmt, als auch im Anschluss eine Koronarangiographie durchgeführt wurde, wurden retrospektiv erfasst. Diese Patienten wurden basierend auf ihrer Entlassdiagnose in eine von zehn Gruppen klassifiziert. Die Höhe des hsTnl bei Aufnahme spielte für die Zuordnung zu den Gruppen keine Rolle. Die Einordnung in die Gruppe ST-Hebungsinfarkt (STEMI) erfolgte basierend auf STHebungen gemäß den ESC/ACCF/AHA/WHF-Leitlinien, auf welchen auch die Definitionen des NichtST-Hebungsinfarktes (NSTEMI) und der instabilen Angina pectoris beruhten. Patienten, die sich mit dem initialen Bild einer instabilen Angina pectoris präsentierten, wurden je nach Befund der Koronarangiographie entweder als koronare Herzkrankheit oder NSTEMI klassifiziert. Zeigte dieser Befund keinen Verschluss, keine subtotale Stenose oder Plaqueruptur, dann erfolgte die Einordnung als koronare Herzkrankheit. Patienten ohne höhergradige Koronarstenosen und ohne jegliche Anhaltspunkte für andere kardiale Erkrankungen wurden als nichtkardialer Brustschmerz klassifiziert. Als Reanimation nicht-ischämischer Ursache wurden Patienten eingeordnet, wenn ihr Kreislaufstillstand nicht durch eine stenosierende koronare Herzerkrankung bedingt war. Diese Gruppe beinhaltete die Diagnosen Sepsis, Intoxikation, Pankreatitis, respiratorische Insuffizienz bei exazerbierter COPD, Laktatazidose, cerebrale Blutung, Bradykardie, dilatative Kardiomyopathie, Long-QT-Syndrom und Herzwandaneurysma. Die Diagnose Tako-Tsubo-Kardiomyopathie wurde gestellt, wenn sich bei der Laevokardiographie die typischen Anzeichen „apical ballooning" und basale Hyperkontraktion bei gleichzeitigem Fehlen hochgradiger Koronarstenosen zeigten. Eine Myokarditis wurde diagnostiziert, wenn der Nachweis einer entzündlichen Myokardschädigung durch typische EKG-Veränderungen, erhöhte Entzündungsparameter im Labor sowie myokardiales Ödem und "late enhancement" im MRT bei gleichzeitiger Abwesenheit hochgradiger Koronarstenosen erbracht werden konnte. Kardiale Dekompensation war als eingeschränkte linksventrikuläre Funktion 
mit oder ohne pulmonalvenöse Stauung ohne hochgradige Koronarstenosen definiert. Eine hypertensive Entgleisung wurde diagnostiziert, wenn Patienten vor oder bei Aufnahme deutlich erhöhte Blutdruckwerte bei gleichzeitigem Fehlen hochgradiger Koronarstenosen zeigten. Patienten, welche die Kriterien für keine der obigen Diagnosen erfüllten, wurden als „Sonstige“ klassifiziert. Dies beinhaltete Patienten, deren Symptome unter anderem durch Anämie, Lungenembolie, diabetische Ketoazidose, Anaphylaxie, Intoxikation oder Hypotonie durch Exsikkose bedingt waren. Die Klassifikation wurde von einem erfahrenen interventionellen Kardiologen überprüft und Patienten wurden ausgeschlossen, wenn ihre definitive Diagnose unklar blieb.

\section{Laborchemische Analyse}

Die Laborwerte wurden aus venösen Blutproben bestimmt, welche direkt nach Entnahme an das Institut für Klinische Chemie und Laboratoriumsmedizin geschickt und dort gemäß standardisierter Protokolle ausgewertet wurden. Gemäß den Gepflogenheiten der Kardiologie wurde ein zweiter Troponintest nach mehreren Stunden entnommen, falls dies medizinisch indiziert war. HsTnl wurde auf einem ADVIA Centaur ${ }^{\circledR}$ TnI-Ultra $^{\text {TM }}$ von Siemens Healthcare Diagnostics Inc. bestimmt. Die immunologische Spezifität des Tests wird durch spezifische mono- und polyklonale Antikörper, welche an N-terminale Aminosäuresequenzen binden, realisiert. Eine hohe Sensitivität wird durch chemolumineszente Moleküle gewährleistet, welche Licht emittieren, sobald sie einer chemischen Reaktion unterliegen. Diese Emissionen werden von einem Detektor registriert. Die 99. Perzentile des Tnl-Ultra $^{\text {TM }}$ Tests liegt bei $0,04 \mathrm{ng} / \mathrm{mL}$. Im klinischen Altag erreicht der Test einen Variationskoeffizienten von $6,01 \%$ bei $0,09 \mathrm{ng} / \mathrm{mL}, 4,50 \%$ bei $1,6 \mathrm{ng} / \mathrm{mL}$ und $3,99 \%$ bei $10,7 \mathrm{ng} / \mathrm{mL}$, worin sich die hohe Sensitivität der Methode zeigt. Daher erfüllt der Test die empfohlenen Richtlinien für die klinische Anwendung bei Patienten mit Verdacht auf akutes Koronarsyndrom. Die analytische Sensitivität des Tests beträgt $0,009 \mathrm{ng} / \mathrm{mL}$. 


\section{Herzkatheteruntersuchung / Koronarangiographie}

Basierend auf den Ergebnissen der Koronarangiographie wurde die koronare Herzkrankheit als 1-, 2oder 3-Gefäßerkrankung definiert, je nach Anzahl der Koronararterien mit einer Stenosierung von mehr als 50\% des Lumens. Wandunregelmäßigkeiten von weniger als 10\% Lumeneinengung ohne linksventrikuläre Wandbewegungsstörungen und mit normalem TIMI-Fluss wurden als normale Koronarien definiert.

\section{Statistische Auswertung}

Alle Angaben zur Alter und Body Mass Index sind als Mittelwerte \pm Standardabweichung, alle Laborparameter als Median und Interquartilsabstand angegeben. Für den Vergleich zwischen Gruppen wurde bei normal verteilten Variablen der T-Test sowie andernfalls der Mann-Whitney UTest verwendet. Das Vorliegen einer Normalverteilung wurde vor Anwendung des T-Tests mittels Kolmogorov-Smirnov-Test und Shapiro-Wilk-Test überprüft. Kategoriale Variablen wurden mittels des Chi-Quadrat-Tests überprüft. Wegen der großen Spannweite der Troponinwerte wurde für die graphische Darstellung in Abbildung 1 eine logarithmische Darstellung gewählt. Um die Vorhersagekraft des hsTnl für einen akuten Myokardinfarkt zu bestimmen, wurde die „Area under the curve“ (AUC) der „Receiver Operating Characteristic“ (ROC)-Kurve bestimmt. Ein p-Wert $<0,05$ wurde als statistisch signifikant angesehen. Die Auswertung wurde mittels PASW Statistics 17 (SPSS Inc.) und MedCalc durchgeführt. 


\section{Ergebnisse}

\section{$\underline{\text { Patientenkollektiv }}$}

Die Mehrheit der Patienten (73\%) präsentierte sich mit dem Bild eines akuten Myokardinfarktes (40\% STEMI, $33 \%$ NSTEMI). Myokarditis war bei 1,9\% und Tako-Tsubo-Kardiomyopathie bei 1,8\% der Patienten die Entlassdiagnose. 9,1\% wiesen eine KHK ohne akute Ischämie auf, 3,8\% eine kardiale Dekompensation und 1,5\% eine hypertensive Entgleisung. 4,8\% der Patienten waren aus letztendlich nicht-ischämischen Gründen reanimiert worden. Nicht-kardialer Brustschmerz wurde bei 1,6\% der Patienten diagnostiziert. Insgesamt war die Mehrheit der Patienten männlichen Geschlechts (im Durchschnitt 73\%), mit Ausnahme der Patienten mit Tako-Tsubo-Kardiomyopathie. In dieser Gruppe war nur einer der siebzehn Patienten männlich (jeweils $p \leq 0,001$ ). Patienten mit Myokarditis waren signifikant jünger (jeweils $p \leq 0,005$ ) und wiesen höhere CRP-Konzentrationen auf (jeweils $p \leq 0,001$ ) als die Patienten in den anderen Gruppen. Bei den Patienten mit Reanimation nicht-ischämischer Ursache wurden signifikant höhere Werte von LDH (jeweils $p \leq 0,006$ ) und Myoglobin (jeweils $p \leq 0,026)$ beobachtet.

\section{$\underline{\text { Spektrum des Aufnahme-hsTnl in den einzelnen Gruppen }}$}

Bei Aufnahme wurden die höchsten Werte des hsTnl bei Patienten mit Myokarditis (Median 9,76 ng/mL), Tako-Tsubo-Kardiomyopathie (Median 2,57 ng/mL) und STEMI (Median 1,27 ng/mL, jeweils $p=$ n.s.) beobachtet. Verglichen mit STEMI war das hsTnl bei Patienten mit NSTEMI (Median 0,66 ng/mL, $p<0,001$ ), Reanimation nicht-ischämischer Ursache (Median 0,31 ng/mL, $p=0,001$ ), kardialer Dekompensation (Median 0,088 ng/mL, $\mathrm{p}<0,001$ ) und hypertensiver Entgleisung (Median $0,066 \mathrm{ng} / \mathrm{mL}, \mathrm{p}=0,001)$ niedriger. Mit einem Median von 0,012 ng/mL bzw. 0,018 ng/mL hatte die Mehrzahl der Patienten mit den Entlassdiagnosen nicht-kardialer Brustschmerz und KHK Werte unter dem empfohlenen Grenzwert von 0,04 ng/mL. 


\section{Maximales hsTnl in den einzelnen Gruppen}

Im Allgemeinen war die Verteilung des maximalen hsTnls während der Verlaufskontrollen ähnlich der Verteilung der Werte bei Aufnahme. Allerdings wurden die höchsten Konzentrationen bei Patienten mit STEMI (Median 32,47 ng/mL) und nicht bei Patienten mit Myokarditis (Median 27,57 ng/mL, $p=$ n.s.) beobachtet. Patienten mit STEMI hatten darüber hinaus signifikant höhere maximale hsTnIWerte als Patienten mit Tako-Tsubo-Kardiomyopathie (Median 5,42 ng/mL, $\mathrm{p}=0,002$ ), NSTEMI (Median 3,36 ng/mL), Reanimation nicht-ischämischer Ursache (Median 1,88 ng/mL), hypertensiver Entgleisung (Median 0,38 ng/mL), kardialer Dekompensation (Median 0,21 ng/mL), KHK (Median $0,030 \mathrm{ng} / \mathrm{mL}$ ) und nicht-kardialem Brustschmerz (Median 0,022 ng/mL; jeweils $\mathrm{p}<0,001$ ). Verglichen mit den hsTnl-Werten bei Aufnahme wurde der größte Anstieg bei Patienten mit STEMI (26-fach) beobachtet, gefolgt von Patienten mit Reanimation nicht-ischämischer Ursache, hypertensiver Entgleisung (jeweils 6-fach), NSTEMI (5-fach), Myokarditis (3-fach), kardialer Dekompensation und Tako-Tsubo-Kardiomyopathie (jeweils 2-fach).

\section{Prädiktive Werte von Aufnahme- und Verlaufswerten des hsTnls für einen akuten Myokardinfarkt}

Die prädiktiven Werte des hsTnls für einen akuten Myokardinfarkt (NSTEMI und STEMI) bei Aufnahme sowie im Verlauf wurden mittels ROC-Analyse bestimmt (AUC 0,748, $p<0,001$ ). Das Aufnahme-hsTnl erreichte eine Sensitivität von $88 \%$ und eine Spezifität von 45\% für den im klinischen Alltag empfohlenen Grenzwert von 0,04 ng/mL. Für einen optimierten Grenzwert von $0,10 \mathrm{ng} / \mathrm{mL}$ lagen die Sensitivität bei 77\% und die Spezifität bei 63\%. Für die alleinige Diagnose eines NSTEMI war die Spezifität für den empfohlenen Grenzwert von $0,04 \mathrm{ng} / \mathrm{mL} 87 \%$ und die Sensitivität 45\%, bzw. 74\% und 63\% für den optimierten Grenzwert von 0,10 ng/mL (AUC 0,725, $\mathrm{p}<0,001$ ).

Darüber hinaus wurden auch die prädiktiven Werte des maximalen hsTnls bei den Verlaufskontrollen untersucht. Hierbei zeigte sich, dass ein Grenzwert von $0,04 \mathrm{ng} / \mathrm{mL}$ bei den Verlaufskontrollen eine Sensitivität von 99\% und eine Spezifität von 35\% für die Diagnose eines akuten Myokardinfarktes 
erreicht. Diese Werte änderten sich auch nach Ausschluss von Patienten mit STEMI nicht. Wurde jedoch ein 10-fach höherer Grenzwert von 0,40 ng/mL als Grundlage herangezogen und Patienten mit STEMI, Tako-Tsubo-Kardiomyopathie, Myokarditis und Reanimation nicht-ischämischer Ursache ausgeschlossen, dann wurden eine Sensitivität von $89 \%$ und eine Spezifität von $85 \%$ für die Diagnose eines NSTEMI erreicht.

\section{Bedeutung des hsTnl für dringliche Koronarangiographien}

In der untersuchten Population wurde nur bei $81 \%$ der Patienten mit hsTnl-Werten $>0,04 \mathrm{ng} / \mathrm{mL}$ letztendlich die Diagnose eines NSTEMI oder STEMI gestellt. Somit wurden $19 \%$ aller Herzkatheteruntersuchungen bei Patienten ohne akuten Myokardinfarkt durchgeführt. Da auch Patienten mit einem Aufnahme-hsTnl $<0,04 \mathrm{ng} / \mathrm{mL}$ koronarangiographiert wurden, lag der Anteil der Patienten ohne akuten Myokardinfarkt bei 27\%. Ausgehend von der Annahme, dass nur Patienten mit hsTnl-Aufnahmewerten über dem optimierten Grenzwert von 0,10 ng/mL koronarangiographiert worden wären, hätte die Rate von Patienten ohne akuten Myokardinfarkt von 27\% auf 15\% gesenkt werden können. 


\section{Diskussion}

Die vorliegende Arbeit untersuchte hsTnl als Marker für den akuten Myokardinfarkt in einer Kohorte von Patienten mit Verdacht auf akutes Koronarsyndrom und folgender Koronarangiographie. Die erhobenen Daten zeigen, dass das hsTnl ein sehr sensitiver Marker für die Detektion einer Myokardschädigung, jedoch unspezifisch für den akuten Myokardinfarkt ist. Weitere potenzielle und klinisch relevante Erkrankungen, die ebenfalls zu einer Erhöhung des hsTnls führen können, sind die kardiale Dekompensation, hypertensive Entgleisung, Myokarditis, Tako-Tsubo-Kardiomyopathie sowie auch eine Reanimation nicht-ischämischer Ursache. Das hsTnl bei Aufnahme erreicht nur dann verlässliche prädiktive Werte, wenn die letzten drei Krankheitsbilder ausgeschlossen werden. Aus diesem Grund liegen die optimierten Grenzwerte für die Diagnose eines akuten Myokardinfarktes oberhalb des Grenzwertes der 99. Perzentile einer gesunden Referenzpopulation. Es zeigte sich weiterhin, dass sich die prädiktiven Werte des hsTnls mit wiederholter Testung verbessern und dass von einem Nicht-ST-Hebungsinfarkt ausgegangen werden kann, wenn das hsTnl im Verlauf über $0,40 \mathrm{ng} / \mathrm{mL}$ ansteigt. Wenn die Entscheidung zur Notfall-Koronarangiographie auf dem hsTnl beruht, müssen bis zu 30\% nicht akut pathologische Koronarbefunde erwartet werden.

\section{$\underline{\text { HsTnl in der Diagnostik des akuten Myokardinfarktes }}$}

Tests basierend auf dem hoch-sensitiven Troponin I haben in anderen Studien für die Diagnose eines akuten Myokardinfarktes Sensitivitäten und Spezifitäten von 84 bis 94 Prozent erreicht. Die vorliegende Arbeit zeigte mit einer Sensitivität von $88 \%$ in dieser Hinsicht ein vergleichbares Ergebnis. Allerdings lag die Spezifität für die Diagnose eines akuten Myokardinfarktes in der untersuchten Kohorte bei einem Grenzwert von 0,04 ng/mL nur bei 45\%. Dieser Unterschied dürfte in erster Linie auf dem unterschiedlichen Studiendesign und den unterschiedlichen Definitionen eines akuten Myokardinfarktes beruhen. In der Studie von Reichlin et al. wurden Patienten eingeschlossen, wenn sie innerhalb von 12 Stunden vor Aufnahme klinische Anzeichen eines akuten 
Myokardinfarktes gezeigt hatten. Ein Myokardinfarkt wiederum wurde definiert als klinische Anzeichen für Myokardischämie in Verbindung mit mindestens einem Troponinwert über der 99. Perzentile. In einer anderen Studie von Keller et al. wurden Patienten eingeschlossen, wenn sie über neu aufgetretene Brustschmerzen klagten. Ein Myokardinfarkt war in dieser Studie als ein Anstieg oder Abfalls des hsTnls von mindestens 30\% innerhalb von sechs Stunden nach Aufnahme des Patienten definiert, wobei mindestens ein Wert über $0,04 \mathrm{ng} / \mathrm{mL}$ liegen musste. Im Vergleich zur vorliegenden Arbeit könnte die Spezifität der hoch-sensitiven Troponintests von den oben genannten Studien insbesondere deswegen überschätzt worden sein, weil die Diagnose eines akuten Myokardinfarktes oftmals nicht mittels Koronarangiographie gesichert wurde. Dies ist insbesondere von Bedeutung, als auch eine Reihe anderer Erkrankungen mit unspezifischen EKG-Veränderungen und erhöhten Troponinwerten einher gehen können.

Im Gegensatz zu den beiden oben genannten Studien ist die Besonderheit der aktuellen Arbeit die Tatsache, dass bei ausnahmslos allen Patienten eine invasive Abklärung der Koronararterien mittels Herzkatheteruntersuchung erfolgte. Sie zeigt, dass Tako-Tsubo-Kardiomyopathie und Myokarditis ebenso wie kardiale Dekompensation, hypertensive Entgleisung und eine Reanimation nichtischämischer Ursache zu signifikant erhöhten hsTnI-Werten führen können und erlaubt es, diese Erhöhungen hinsichtlich ihres Ausmaßes einzuordnen. Letztendlich zeigt die vorliegende Arbeit im Einklang mit anderen Studien, dass es unmöglich ist, einen akuten Nicht-ST-Strecken-Hebungsinfarkt allein aufgrund erhöhter hsTnl-Werte von einer nicht-ischämischen Myokardschädigung mit hinreichender Sicherheit zu unterscheiden.

$\underline{\text { Verbesserung der prädiktiven Werte des hsTnls bei der Diagnostik des akuten Myokardinfarktes }}$

Zur Verbesserung der prädiktiven Werte des hsTnls für die Diagnose eines akuten Myokardinfarktes wurden zwei Strategien untersucht, einerseits höhere Grenzwerte und andererseits Verlaufskontrollen. Die Grenzwerte für das hsTnl bei den Aufnahme- oder Verlaufsbestimmungen zu 
erhöhen verringert in der Tat deutlich die Anzahl „positiver“ Ergebnisse bei Patienten ohne Myokardinfarkt. Allerdings reduziert es gleichzeitig auch die Anzahl positiver Ergebnisse bei Patienten mit NSTEMI, ein Effekt, der bei den Aufnahmewerten stärker ausgeprägt ist als bei den Verlaufskontrollen. Nach Ausschluss von Patienten mit STEMI, welche keine positiven Labormarker für das Stellen der Diagnose benötigen, lag die Sensitivität für die Diagnose eines akuten Myokardinfarktes, also eines NSTEMI, bei $87 \%$, die Spezifität bei 45\%. Erst nach Ausschluss von TakoTsubo-Kardiomyopathie, Myokarditis und Reanimation nicht-ischämischer Ursache erreichten die prädiktiven Werte des Aufnahme-hsTnls ein aussagekräftiges Niveau. Der optimierte Grenzwert überschritt hierbei die 99. Perzentile der gesunden Referenzpopulation und lag bei 0,10 ng/mL.

Bei den Verlaufskontrollen wurden mit einer Sensitivität von $89 \%$ und einer Spezifität von $85 \%$ ausgezeichnete prädiktive Werte für die Diagnose eines NSTEMI erzielt, wenn ein 10-fach höherer Grenzwert von $0,40 \mathrm{ng} / \mathrm{mL}$ für das maximale hsTnl zu Grunde gelegt, sowie Patienten mit STEMI, Tako-Tsubo-Kardiomyopathie, Myokarditis und Reanimation nicht-ischämischer Ursache ausgeschlossen wurden. Obwohl der Ausschluss dieser Erkrankungen einen gewissen Selektionsbias mit sich bringt, erscheint er doch gerechtfertigt, da diese Erkrankungen einerseits relativ selten sind. Zum anderen präsentieren sie sich häufig hoch akut und eine dringliche Koronarangiographie ist oftmals indiziert, um einen akuten Myokardinfarkt mit Sicherheit auszuschließen. Im Gegensatz dazu müssen viel häufigere Erkrankungen wie kardiale Dekompensation und hypertensive Entgleisung, welche ebenfalls mit erhöhtem hsTnl einhergehen, jedoch keine dringliche Koronarangiographie erfordern, mit größtmöglicher Zuverlässigkeit von einem akuten Myokardinfarkt differenziert werden können. In dieser Hinsicht gewährleistete die untersuchte Vorgehensweise, bei Verlaufskontrollen einen akuten Myokardinfarkt erst dann anzunehmen, wenn das maximale $\mathrm{hsTnl}$ über $0,40 \mathrm{ng} / \mathrm{mL}$ ansteigt, die beste Unterscheidung. Während das hsTnl bei Patienten mit NSTEMI bei $89 \%$ der Patienten im Verlauf über $0,40 \mathrm{ng} / \mathrm{mL}$ anstieg, überschritten nur $30 \%$ der Patienten mit anderen Diagnosen diesen Wert, wenn STEMI, Tako-Tsubo-Kardiomyopathie, Myokarditis und Reanimation nicht-ischämischer Ursache ausgeschlossen wurden. Diese absolute Differenz von fast 60 
Prozentpunkten wurde von keiner anderen Strategie, also keinem anderen möglichen Grenzwert bei Aufnahme oder im Verlauf, erreicht.

Als mögliche praktische Vorgehensweise wurde daher eine Strategie entwickelt, welche in Abbildung 3 der Arbeit dargestellt ist. Diese Strategie sollte im Weiteren noch prospektiv getestet werden. Möglicherweise könnte eine derartige Strategie auch dazu beitragen, unnötige Verlaufskontrollen zu vermeiden und somit Kosten zu sparen. Des Weiteren sollten die aktuellen Leitlinien für die Diagnose eines akuten Myokardinfarktes nicht-ischämische Erhöhungen des hsTnls sowie deren Auswirkung auf die korrekte Diagnose eines akuten Myokardinfarktes besser berücksichtigen.

Als eine Alternative zur wiederholten Bestimmung des Troponins wurde in anderen Studien die Mitbestimmung von Copeptin bei Patienten mit negativem ersten Troponintest vorgeschlagen, um das nötige Zeitintervall für den Ausschluss eines NSTEMI zu reduzieren. Weitere Studien werden hier bei der Klärung der Frage behilflich sein, wo die jeweiligen Vorteile der Verlaufsbestimmung des hsTnls alleine sowie der Bestimmung von hsTnl zusammen mit Copeptin liegen.

Eine weitere Möglichkeit ist die gleichzeitige Bestimmung von NT-proBNP, welches nachgewiesenermaßen die Ischämie, die erfolgreiche Reperfusion sowie die Prognose bei Patienten mit akutem Koronarsyndrom widerspiegelt.

\section{Bedeutung des erhöhten hsTnls für die dringliche Koronarangiographie}

Patienten mit akutem Myokardinfarkt in der Notaufnahme verlässlich zu identifizieren ist für den behandelnden Arzt oftmals eine Herausforderung. Da Zeit ein entscheidender Faktor bei diesem Krankheitsbild ist, werden in vielen Kliniken Patienten auch bei nur minimalen Troponinerhöhungen umgehend koronarangiographiert, selbst wenn dies in einer relevanten Zahl von "falsch positiven" Untersuchungsindikationen resultiert. Davon abgesehen können auch nur geringfügige Erhöhungen 
des hsTnls mit einer erhöhten Langzeitsterblichkeit assoziiert sein und darüber hinaus auf kardiale Erkrankungen hinweisen, die einer weiteren Abklärung und Behandlung bedürfen. Da zudem die Vorteile einer zügigen invasiven Therapie bei Patienten mit akutem Myokardinfarkt überwiegen, muss ein gewisser Prozentsatz an unauffälligen Koronarangiographien bei Patienten mit erhöhtem hsTnl (und folglich vermutetem NSTEMI) wegen der niedrigen Spezifität des hsTnls in Kauf genommen werden. Allerdings mag es auf der Basis dieser Arbeit und anderer Studien angebracht sein, die Koronarangiographie bei stabilen Patienten ohne akute Brustschmerzen zu verschieben, wenn das hsTnl nur gering erhöht ist (z.B. zwischen 0,04-0,40 ng/mL) und im weiteren Verlauf nicht weiter ansteigt.

\section{Limitationen}

Da nur Patienten mit Koronarangiographie und der Bestimmung von hsTnl eingeschlossen wurden, liegt ein gewisser Selektionsbias hinsichtlich des Spektrums an möglichen kardialen Erkrankungen vor. Allerdings ist die Koronarangiographie unabdingbare Voraussetzung, da sie die einzige Möglichkeit ist, die korrekte Diagnose zu sichern. Weitere mögliche Limitationen sind, dass die verwendeten Daten retrospektiv und nur an einer Klinik erhoben wurden und dass die Verlaufsbestimmungen des hsTnls nicht fest vorgegeben waren, sondern nach klinischer Indikation durchgeführt wurden. 


\section{Zusammenfassung}

Die vorliegende Arbeit untersuchte das hsTnl bei akuten kardialen Erkrankungen in einer Kohorte von Patienten mit invasiver Koronarangiographie. Es zeigt sich, dass das hsTnl ein sensitiver, aber unspezifischer Marker für die myokardiale Ischämie ist, da auch eine Reihe nicht-ischämischer Erkrankungen zu relevanten Erhöhungen dieses Laborwertes führen können. Den Grenzwert des hsTnls über die 99. Perzentile einer gesunden Referenzpopulation anzuheben, z.B. von 0,04 ng/mL auf $0,10 \mathrm{ng} / \mathrm{mL}$, verbessert die Spezifität für einen akuten Myokardinfarkt bei gleichzeitig noch akzeptabler Sensitivität. Es zeigt sich weiterhin, dass im klinischen Alltag die Koronarangiographie bei Patienten mit erhöhten hsTnl-Werten notwendigerweise mit einer relevanten Anzahl an unauffälligen Koronarbefunden sowie mit im Nachhinein nicht indizierten Notfalluntersuchungen einhergeht. Ein Grenzwert von $0,40 \mathrm{ng} / \mathrm{mL}$ initial oder bei der Verlaufskontrolle gewährleistet akzeptable prädiktive Werte des hsTnls für die Diagnose eines akuten Myokardinfarktes und erlaubt es, einen NSTEMI besser von nicht-ischämischen Erkrankungen differenzieren zu können. 


\section{Danksagung}

Vor allem und daher an erster Stelle gilt mein besonderer Dank meinem Doktorvater, Herrn Prof. Dr. Andreas Luchner, nicht nur für die freundliche Überlassung des Themas, sondern insbesondere für die exzellente Betreuung, sein herausragendes Engagement und seine stets freundliche Unterstützung sowie Motivation bei der Erstellung dieser Arbeit und darüber hinaus. Die zahlreichen, stets zeitnahen Treffen sowie die unzähligen von ihm investierten Stunden haben maßgeblich zum erfolgreichen Abschluss des Publikationsverfahrens beigetragen.

Herrn Prof. Dr. Günter Riegger danke ich für die Möglichkeit, diese Arbeit an seinem Lehrstuhl durchführen zu können.

Ferner möchte ich allen Coautoren für die freundliche und konstruktive Kritik sowie die Unterstützung beim Erstellen der Publikation danken, hier insbesondere Herrn Dr. Stefan Buchner, Herrn Dr. Carsten Jungbauer sowie Herrn PD Dr. Kurt Debl und Herrn PD Dr. Dierk Endemann. Frau Dr. Petra Lehn vom Institut für Klinische Chemie und Laboratoriumsmedizin danke ich darüber hinaus auch für die umfassende Unterstützung bei allen Fragen hinsichtlich der laborchemischen Hintergründe.

Des Weiteren danke ich Herrn Markus Solleder aus der EDV-Abteilung des Instituts für Klinische Chemie und Laboratoriumsmedizin für die tatkräftige Hilfe bei der Zusammenstellung der Labordaten.

Außerdem gilt mein Dank dem gesamten Team des Herzkatheterlabores, welches mich bei der Erhebung der Daten stets freundlich empfangen hat.

Zu guter Letzt möchte ich mich herzlich bei meinen Eltern sowie meinen Freunden für die uneingeschränkte Unterstützung während des gesamten Studiums und der Erstellung dieser Arbeit bedanken. 
PERSÖNLICHE DATEN

Tobias Gassenmaier

* 1985, Erlangen

BERUFLICHE LAUFBAHN

Seit $02 / 2012$

Assistenzarzt am Institut für Röntgendiagnostik (Prof. Dr. D. Hahn), Universitätsklinikum Würzburg

PRAKTISCHES JAHR

06/2011-07/2011

Klinik und Poliklinik für Innere Medizin I (Prof. Dr. B. Salzberger), Universitätsklinikum Regensburg

$04 / 2011-06 / 2011$

Department of Cardiology (Prof. A. Fenech), Mater Dei Hospital, Msida, Malta

$04 / 2011$

$01 / 2011-04 / 2011$

$12 / 2010-01 / 2011$

$08 / 2010-12 / 2010$

Klinik und Poliklinik für Innere Medizin II (Prof. Dr. G. Riegger), Universitätsklinikum Regensburg

Klinik für Allgemein-, Visceral-, Thorax-, Gefäss- und Unfallchirurgie (Dr. A. Zerz), Kantonsspital Bruderholz, Schweiz

Klinik und Poliklinik für Chirurgie (Prof. Dr. H. J. Schlitt), Universitätsklinikum Regensburg

Institut für Röntgendiagnostik (Prof. Dr. C. Stroszczynski), Universitätsklinikum Regensburg

\section{AUSBILDUNG}

$10 / 2011$

$10 / 2007-10 / 2011$

09/2007

$10 / 2005-09 / 2007$

$1996-2005$

\section{WISSENSCHAFTLICHE ARBEITEN}

$02 / 2012$

$04 / 2010$

Gassenmaier T, Buchner S, Birner C, Jungbauer CG, Resch M, Debl K, Endemann DH, Riegger GAJ, Lehn P, Schmitz G, Luchner A. High-sensitive Troponin I in acute cardiac conditions: Implications of baseline and sequential measurements for diagnosis of myocardial infarction. Atherosclerosis 222 (2012) pp. 116-122

Gassenmaier T, Buchner S, Lehn P, Jungbauer C, Birner C, Resch M, Debl K, Riegger G, Luchner A. Hochsensitives Troponin I ist nicht spezifisch für akute Myokardischämien: retrospektive Analyse einer unselektionierten Kohorte von Patienten mit dringlicher Herzkatheter-Untersuchung.

Vortrag auf der 76. Jahrestagung der Deutschen Gesellschaft für Kardiologie, Mannheim, 2010 (Abstract: Clin Res Cardiol 99, Suppl 1, April 2010, V 1529) 